Vol. 11 (2002): 273-284.

\title{
Monitoring of Finnish arable land: changes in soil quality between 1987 and 1998
}

Ritva Mäkelä-Kurtto and Jouko Sippola

MTT Agrifood Research Finland, Environmental Research, FIN-31600 Jokioinen, Finland,

e-mail: ritva.makela-kurtto@mtt.fi

\begin{abstract}
This study is part of the long-term monitoring of Finnish arable land and it is based on soil analyses of 705 monitoring sites sampled in 1998. The same sites were sampled twice previously, in 1974 and 1987. We describe here the state of the Finnish cultivated soils in 1998 and changes in soil quality since 1987. The samples were analysed for organic C, volume weight, $\mathrm{pH}, \mathrm{P}, \mathrm{K}, \mathrm{Ca}, \mathrm{S}, \mathrm{Mg}, \mathrm{Al}, \mathrm{B}, \mathrm{Cd}$, $\mathrm{Co}, \mathrm{Cr}, \mathrm{Cu}, \mathrm{Fe}, \mathrm{Mn}, \mathrm{Mo}, \mathrm{Se}$ and $\mathrm{Zn}$. Macronutrients were extracted with $0.5 \mathrm{M}$ ammonium acetate + $0.5 \mathrm{M}$ acetic acid ( $\mathrm{pH} 4.65)$ and most micronutrients, $\mathrm{Al}$ and heavy metals with the same solution + $0.02 \mathrm{M} \mathrm{Na}_{2}$ EDTA. Hot water was used to extract B and Se.

From 1987 to 1998 , soil $\mathrm{P}, \mathrm{Ca}, \mathrm{Mg}, \mathrm{S}, \mathrm{Cr}, \mathrm{Cu}, \mathrm{Zn}$, volume weight and electrical conductivity increased and soil $\mathrm{K}, \mathrm{B}, \mathrm{pH}$ and organic $\mathrm{C}$ decreased. There was no change in soil $\mathrm{Al}, \mathrm{Cd}, \mathrm{Mn}$ and $\mathrm{Ni}$. Between 1987 and 1998, the use of P, K, B and Cu in mineral fertilisers declined whereas that of Ca in liming agents and $\mathrm{Zn}$ in mineral fertilisers increased. With the exception of $\mathrm{P}$ and $\mathrm{Cu}$, these changes affected the concentrations of easily soluble macro- and micronutrients in the soil accordingly. The slight decrease in soil $\mathrm{pH}$ might be due to the increase in the use of fertliser $\mathrm{N}$. The finding that soil $\mathrm{Cd}$ and $\mathrm{Ni}$ ceased to increase and that soil $\mathrm{Cr}$ increased only slightly was attributed to the dramatic reduction in national emissions and bulk depositions of heavy metals.
\end{abstract}

Key words: cultivated soil, heavy metals, macronutrients, trace elements, soil monitoring, soil testing

\section{Introduction}

The quality of cultivated soils is of a great agricultural, nutritional and environmental importance to society. Soil can be considered as the most valuable natural resource for our food supply, as $95 \%$ of protein and most of the calories needed by human population are obtained from traditional land-based agriculture (Botkin and Keller 1995). Fertile, uncontaminated soil can yield crops sufficient in quantity and high in quality. Soil quality is known to have marked effects on health (Oliver 1997). Furthermore, soil has impacts on the environment, particularly on the quality of surface waters and groundwaters. 


\section{Mäkelä-Kurtto, R. \& Sippola, J. Monitoring of Finnish arable land}

In Finland, the eutrophication of the surface waters is caused mainly by $\mathrm{N}$ and $\mathrm{P}$ leached from arable land. Agriculture and other human activities affect soil quality and soil physical, chemical and biological processes. Soil is susceptible to pollutant inputs from natural and anthropogenic sources, such as atmospheric depositions and agro-chemicals. One of the most harmful pollutant groups in the food chain is heavy metals.

The state of cultivated soils has been monitored to help us meet the targets of sustainable agriculture, to maintain high quality of the crops and to reduce nutrient load on waters. Monitoring is a way of following-up soil quality and changes in it with time. These changes are caused mainly by agricultural management practices such as fertilisation, liming, and the application of manure and organic soil improvers including sewage sludge. Atmospheric deposition is a significant source, at least locally, of some elements, e.g., polluting heavy metals.

This study was conducted as part of the longterm monitoring of Finnish cultivated soils. Soil quality was analysed by using methods applied in Finnish soil testing (Vuorinen and Mäkitie 1955, Lakanen and Erviö 1971). The fertiliser recommendations and restrictions set out in EU agri-environmental legislation and financial support received from the EU are based on soil testing, too. The same analytical methods were used in a global FAO soil testing project (Sillanpää 1982, 1990, Sillanpää and Jansson 1992, Jansson 1995).

Finland has two monitoring networks for cultivated soils, one comprising 705 sites, which has been operating at country level since 1974, and a smaller one with 122 sites, which was set up at experimental stations of MTT Agrifood Research Finland since 1992 (Starr et al. 2000). The monitoring of arable land at country level began in 1974 with the collection of soil samples from 2000 field plots throughout the cultivated area (Sippola and Tares 1978). In 1987, 1320 sites of the same fields were resampled in a project under the Finnish Acidification Programme (Erviö et al. 1990). In 1998, the same monitoring sites, covering a total of 705 fields, were sampled for a third time.

The main aims of this study were to present the state of Finnish cultivated soils in 1998, changes in soil quality since 1987 and to establish the most probable reasons for the changes. Excluding phosphorus, sulphur, copper and zinc, analytical results were not presented in this paper by cultivation zone, because the data for 1998 did not differ markedly from those for 1987 , which were published earlier (Erviö et al. 1990). Also, the distributions of element concentrations of the soils in 1987 are available in the earlier publication.

\section{Material and methods}

This long-term soil monitoring study has been conducted by keeping the sampling sites, season and methods unaltered since the beginning. Thus, in 1998, soil samples were collected from the surface layer $(0-20 \mathrm{~cm})$ of arable land as four subsamples from each corner of a $10 \times 10 \mathrm{~m}$ sampling area as they had been in 1974 (Sippola and Tares 1978) and in 1987 (Erviö et al. 1990). The sampling season was early summer, by which time timothy had formed a full spike. Note that all fields had most likely been fertilised 1-2 months before the time of sampling. The number of sampled sites totalled 705 (Fig. 1). The samples were air-dried and passed through a 2-mm sieve before analysis.

Soil analyses methods employed in 1998 were the same as those used in the previous monitoring studies (Erviö et al. 1990) and in the soil testing of cultivated soils in Finland (Agricultural Research Centre 1986, Viljavuuspalvelu 2000). Electrical conductivity (EC) and $\mathrm{pH}\left(\mathrm{H}_{2} \mathrm{O}\right)$ were measured from a soil-water suspension (1:2.5). Volume weight was determined by weighing $25 \mathrm{ml}$ of air-dried and ground soil. Carbon (C) content was determined by an automated dry ashing method (LECO CR-12, St. Joseph, MI, USA.) assuming that the sample 
Vol. 11 (2002): 273-284.

contained only organic C. For the air-dried soil samples, $0.5 \mathrm{M}$ ammonium acetate $+0.5 \mathrm{M}$ acetic acid (pH 4.65, AAAc) $(1: 10,1 \mathrm{~h})$ was used to extract the macroelements phosphorus $(\mathrm{P})$, potassium $(\mathrm{K})$, calcium $(\mathrm{Ca})$, magnesium $(\mathrm{Mg})$, sulphur (S) and $0.5 \mathrm{M}$ ammonium acetate +0.5 $\mathrm{M}$ acetic acid + 0.02 $\mathrm{M} \mathrm{Na}_{2}$ EDTA (pH 4.65, AAAc-EDTA) $(1: 10,1 \mathrm{~h})$ was used to extract aluminium (Al), cadmium (Cd), cobalt (Co), chromium $(\mathrm{Cr})$, copper $(\mathrm{Cu})$, iron $(\mathrm{Fe})$, manganese $(\mathrm{Mn})$, molybdenum (Mo) and zinc $(\mathrm{Zn})$. Boron (B) and selenium (Se) were extracted with boiling water (1:2, $5 \mathrm{~min}, 1: 4,30 \mathrm{~min}$, respectively). All the reported results were based on 25-ml soil volumes taken for extraction. Concentrations of $\mathrm{P}$ were measured by spectrophotometry, $\mathrm{K}, \mathrm{Ca}, \mathrm{Mg}, \mathrm{S}, \mathrm{Al}, \mathrm{B}, \mathrm{Cd}, \mathrm{Co}, \mathrm{Cr}, \mathrm{Cu}$, $\mathrm{Fe}, \mathrm{Mn}$ and $\mathrm{Zn}$ by inductively coupled plasma emission optic spectrometry (ICP-OES), Mo by graphite furnace atomic absorption spectrometry (GF-AAS) and Se by inductively coupled plasma mass spectrometry (ICP-MS). A main difference in the laboratory devices used for the measurements of soil characteristics between 1987 and 1998 was that the concentration of Cd in the soil extracts were measured by AAS using an air-acetylene flame in 1987 (Erviö et al. 1990).

Due to the non-normality of distributions, statistical evaluation of analytical results was carried out by the sign test of the UNIVARIATE procedure (SAS 1999). Test statistics were calculated from the difference in data from the same site between 1987 and 1998. Probabilities P < 0.05 of the sign test value for analysed soil properties were considered to indicate a significant change between 1987 and 1998.

\section{Results and discussion}

\section{Soil types and general soil characteristics}

Soil types. In 1998, the 705 soil samples (Fig. 1) were classified into soil type groups as follows:

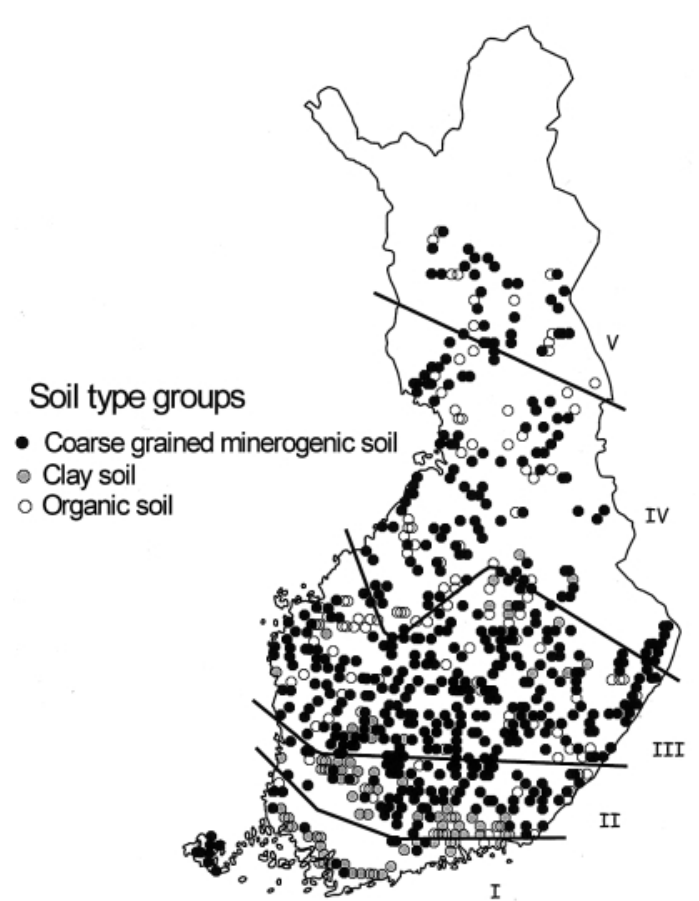

Fig. 1. Sampling sites $(\mathrm{n}=705)$ in 1998 by the soil type groups and by the plant cultivation zones, I-V.

coarse grained minerogenic soils (sands and silts) $69 \%$; clay soils (clay content $>30 \%$ ) $14 \%$; and organic soils (humus content $>20 \%$ ) $17 \%$. The figures for 1987 were $67 \%, 14 \%$ and $19 \%$, respectively, indicating that some soils classified as organic in 1987 had been converted due to organic matter decomposition into coarse grained minerogenic soils by 1998 .

Organic carbon. The median organic C content of the soils in 1998 was down by $8 \%$ on 1987 whereas the median soil volume weight was up by $5 \%$ (Table 1). These small changes might be due to the decomposition of organic matter and to soil compaction. Soil volume weight is known to depend on the humus content (Erviö 1970). Moreover, current cropping systems favour decomposition of soil organic matter (Erviö 1995). Organic C content was higher, on average, in the north than in the south of the country due to the abundance of peat and other organic soils in northern Finland (Fig. 1). 
Mäkelä-Kurtto, R. \& Sippola, J. Monitoring of Finnish arable land

Soil $\mathrm{pH}$. Monitoring of Finnish arable land indicated that soil $\mathrm{pH}\left(\mathrm{H}_{2} \mathrm{O}\right)$ had a decreasing trend, because the median soil $\mathrm{pH}$ value in 1998 was 0.07 units lower than the respective value in 1987. The statistics of Viljavuuspalvelu (2002) also showed an increase in the acidity of Finnish cultivated soils during the study period.

In 1987-1998, the amount of liming agents applied annually to the cultivated area rose, annual sales increasing from $774143 \mathrm{t}(339 \mathrm{~kg}$ $\left.\mathrm{ha}^{-1}\right)$ in $1974-1986$ to $888540 \mathrm{t}\left(460 \mathrm{~kg} \mathrm{ha}^{-1}\right)$ in 1987-1998 (Kemira Agro 1999). As to acidifying emissions into the air in Finland, annual sulphur dioxide $\left(\mathrm{SO}_{2}\right)$ emissions fell from over $300 \mathrm{kt}$ to $90 \mathrm{kt}$ in 1987-1998 but annual nitrous oxide $\left(\mathrm{NO}_{\mathrm{x}}\right)$ emissions remained fairly constant, at 250-300 kt (Saarinen 2001). In cultivation zone $\mathrm{I}$, bulk deposition of sulphate as sulphur $\left(\mathrm{SO}_{4}-\mathrm{S}\right)$ was about $5-10 \mathrm{~kg}$, of nitrate as nitrogen $\left(\mathrm{NO}_{3}-\mathrm{N}\right) 2-4 \mathrm{~kg}$ and of ammonium as nitrogen $\left(\mathrm{NH}_{4}-\mathrm{N}\right) 2-5 \mathrm{~kg} \mathrm{ha}^{-1}$ in 1987-1998; in cultivation zone $\mathrm{V}$, the figures were about $2 \mathrm{~kg}, 1 \mathrm{~kg}$ and under $1 \mathrm{~kg}$, respectively (Leinonen 1999a, b). Depositions were higher in the south than in the north of Finland due to the long-range transport from other European countries including Russia.

Obviously, atmospheric deposition had a minor effect on the $\mathrm{pH}$ of cultivated soils in 1987-1998. The main causes of acidification of cultivated soils in Finland are the application of fertilisers to the soil and the uptake of nutrients by plants from the soil. In 1987-1998, the mean annual use of $\mathrm{N}$ fertilisers was $97 \mathrm{~kg} \mathrm{ha}^{-1}$. This figure was $14 \mathrm{~kg}$ higher than the respective figure in the previous monitoring period (Kemira Agro 1999) and may largely explain the decrease in soil $\mathrm{pH}$ despite the increased use of liming materials.

Electrical conductivity. There was a relatively large difference $(25 \%)$ in EC between the data for 1987 and 1998. The discrepancy was most likely due to periodical fluctuations in values caused by variable weather conditions. The EC level was still very low, however, and no problems are foreseen.

\section{Macronutrients}

Phosphorus. In 1998, the median soil $\mathrm{P}$ value for all the fields studied was $8.5 \mathrm{mg} \mathrm{l}^{-1}$, which was $17 \%$ higher than the respective value in 1987 (Table 1). In 1998, the number of fields with a low $\mathrm{P}$ value was conspicuously lower, but there were also more fields with a high $\mathrm{P}$ value than in 1987 (Fig. 2). There were not big differences in the $\mathrm{P}$ value between soil type groups, on average (Fig. 3). In 1998, regionally, the highest mean $P$ value occurred in the southernmost Finland (Fig. 4). Other data (Viljavuuspalvelu 2002, Palva et al. 2001) also indicate an increasing trend in the soil $\mathrm{P}$ value.

During the monitoring period, the mean annual application rate of $\mathrm{P}$ in mineral fertilisers declined by two-thirds, from $31 \mathrm{~kg}$ in 1987 to $12 \mathrm{~kg} \mathrm{ha}^{-1}$ in 1998. Implementation of the EU agroenvironmental programme in Finnish agriculture in the 1990s reduced the use of $\mathrm{P}$ in fertilisation. The average amount of $\mathrm{P}$ added as mineral fertilisers during the period was $22 \mathrm{~kg}$ $\mathrm{ha}^{-1} \mathrm{yr}^{-1}$ (Kemira Agro 1999). The average application rate of $\mathrm{P}$ fertilisers was down by $7.5 \mathrm{~kg} \mathrm{ha}^{-1}$ on the previous study period. The average amount of $P$ from animal manure, if it is considered to be applied evenly to the whole cultivated area, remained the same, about $10 \mathrm{~kg}$ $\mathrm{ha}^{-1} \mathrm{yr}^{-1}$ (Yli-Halla et al. 2001). Finnish data on $\mathrm{P}$ depositions were not available, but $\mathrm{P}$ inputs from the atmosphere in Continental Europe have varied between 0.05 and $1.1 \mathrm{~kg} \mathrm{ha}^{-1} \mathrm{yr}^{-1}$ (Gibson 1997). Uptake of $P$ by the most common Finnish crops has long been about $10 \mathrm{~kg} \mathrm{ha}^{-1} \mathrm{yr}^{-1}$. Losses of total $\mathrm{P}$ from agriculture to surface waters in Finland has varied between 0.6 and $1.8 \mathrm{~kg} \mathrm{ha}^{-1}$ $\mathrm{yr}^{-1}$ (Rekolainen et al. 1997). The $\mathrm{P}$ balance in Finnish cultivated soils at country level was still positive, the $\mathrm{P}$ application rate being high at the beginning of the study period. Soil $\mathrm{P}$ storage increased substantially and this was not compensated by the lower application rates used later, which were still above the average $P$ uptake of the crop. As a result, the total amount of $\mathrm{P}$ in the plough layer increased annually by about $10 \mathrm{~kg}$ $\mathrm{ha}^{-1}$ in 1987-1998. This clearly led to P test value. 
Vol. 11 (2002): 273-284.

Table 1. Medians and means \pm standard deviation of chemical characteristics of soils $(n=705)$ in 1998 as well as their differences from 1987.

\begin{tabular}{|c|c|c|c|c|c|c|}
\hline & $\begin{array}{c}\text { Median } \\
1998 \\
\left(\mathrm{mg} \mathrm{l}^{-1}\right)\end{array}$ & $\begin{array}{l}\text { Difference } \\
\text { from } 1987 \\
\left(\mathrm{mg} \mathrm{l}^{-1}\right)^{1}\end{array}$ & $\%$ & $\begin{array}{c}\text { Mean } \pm \text { SD } \\
1998 \\
\left(\mathrm{mg} \mathrm{l}^{-1}\right)\end{array}$ & $\begin{array}{c}\text { Difference } \\
\text { from } 1987 \\
\left(\mathrm{mg} \mathrm{l}^{-1}\right)\end{array}$ & $\%$ \\
\hline $\mathrm{pH}\left(\mathrm{H}_{2} \mathrm{O}\right)$ & 5.8 & $-0.07 * * *$ & & $5.8 \pm 0.5$ & -0.04 & \\
\hline Org. C, \% & 3.3 & $-0.28 * * *$ & -8 & $8.3 \pm 11.0$ & -0.73 & -9 \\
\hline Volume weight & 1.0 & $+0.05 * * *$ & +5 & $1.0 \pm 0.2$ & +0.04 & +4 \\
\hline El. cond. $10^{-4} \mathrm{~S} \mathrm{~cm}^{-1}$ & 0.9 & $+0.18 * * *$ & +25 & $1.1 \pm 0.7$ & +0.24 & +28 \\
\hline $\mathrm{Ca}$ & 1237 & $+46^{* *}$ & +4 & $1436 \pm 917$ & +89 & +7 \\
\hline $\mathrm{K}$ & 91 & $-4^{*}$ & -4 & $111 \pm 79$ & -3 & -2 \\
\hline $\mathrm{Mg}$ & 161 & $+6^{*}$ & +4 & $202 \pm 164$ & +14 & +7 \\
\hline $\mathrm{P}$ & 8.5 & $+1.2 * * *$ & +17 & $13.1 \pm 15.1$ & +2.3 & +22 \\
\hline $\mathrm{S}$ & 18 & $+2.8 * * *$ & +18 & $25 \pm 33$ & +5.3 & +28 \\
\hline $\mathrm{Al}$ & 438 & $+5.1 \mathrm{NS}$ & +1 & $493 \pm 276$ & -4.8 & -1 \\
\hline $\mathrm{B}$ & 0.52 & $-0.01 *$ & -2 & $0.59 \pm 0.30$ & -0.03 & -5 \\
\hline $\mathrm{Cd}$ & 0.073 & $+0.002 \mathrm{NS}$ & +2 & $0.080 \pm 0.042$ & +0.003 & +4 \\
\hline $\mathrm{Co}$ & 0.52 & $-0.02 * *$ & -4 & $0.64 \pm 0.50$ & -0.02 & -4 \\
\hline $\mathrm{Cr}$ & 0.28 & $+0.02 * * *$ & +6 & $0.36 \pm 0.29$ & +0.02 & +7 \\
\hline $\mathrm{Cu}$ & 3.6 & $+0.48 * * *$ & +17 & $4.5 \pm 3.7$ & +0.60 & +15 \\
\hline $\mathrm{Fe}$ & 519 & $+20 * *$ & +4 & $742 \pm 685$ & +20 & +3 \\
\hline $\mathrm{Mn}$ & 43 & $-0.3 \mathrm{NS}$ & -1 & $58 \pm 74$ & 0 & \\
\hline Mo & 0.039 & $-0.002 * *$ & -5 & $0.057 \pm 0.070$ & -0.008 & -12 \\
\hline $\mathrm{Ni}$ & 0.61 & $+0.01 \mathrm{NS}$ & +2 & $0.98 \pm 1.03$ & +0.01 & +1 \\
\hline $\mathrm{Se}$ & 0.009 & & & $0.010 \pm 0.005$ & & \\
\hline $\mathrm{Zn}$ & 3.0 & $+0.38 * * *$ & +16 & $4.3 \pm 4.1$ & +0.79 & +22 \\
\hline
\end{tabular}

${ }^{1}$ Statistical significance: $* \mathrm{P}<0.05, * * \mathrm{P}<0.01$, *** $\mathrm{P}<0.001, \mathrm{NS}$ not significant

Potassium. During the monitoring period, soil $\mathrm{K}$ decreased. Restrictions on the use of $\mathrm{N}$ and $\mathrm{P}$ in fertilisation also reduced the use of $\mathrm{K}$ in mineral fertilisers, from $57 \mathrm{~kg} \mathrm{ha}^{-1}$ in 1987 to $33 \mathrm{~kg}$ $\mathrm{ha}^{-1}$ in 1998. In 1987-1998, the mean annual application rate of $\mathrm{K}$ was $44 \mathrm{~kg} \mathrm{ha}^{-1}$, which was $7 \mathrm{~kg}$ less than that in 1974-1987 (Kemira Agro 1999). Research results of Viljavuuspalvelu (2002) were consistent with the present findings. Potassium concentrations were highest in clay soils, the bulk of which are located in southern Finland (Fig. 1).

Calcium. Soil Ca increased by $4 \%$ in $1987-$ 1998 , in harmony with the increase in the use of liming agents during the same period. Likewise soils analysed by Viljavuuspalvelu (2002) showed that the Ca level in 1998 was the same as or slightly higher than in 1986-1990 and in 1991-1995. Coarse grained minerogenic soils had lower $\mathrm{Ca}$ values than either of the other soil type groups had. There was a decreasing trend in soil $\mathrm{Ca}$ towards the north, because coarse grained minerogenic soils were more abundent there than in the south (Fig. 1).

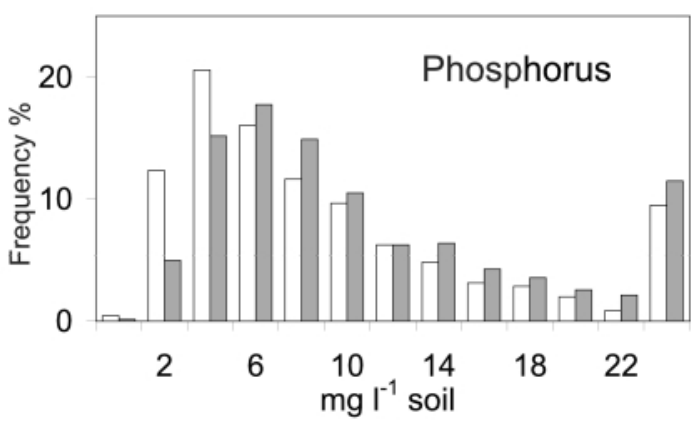

Fig. 2. Distribution of soil extractable phosphorus in 1987 ( $\square)$ and in 1998 ( $\square)$. 
Mäkelä-Kurtto, R. \& Sippola, J. Monitoring of Finnish arable land
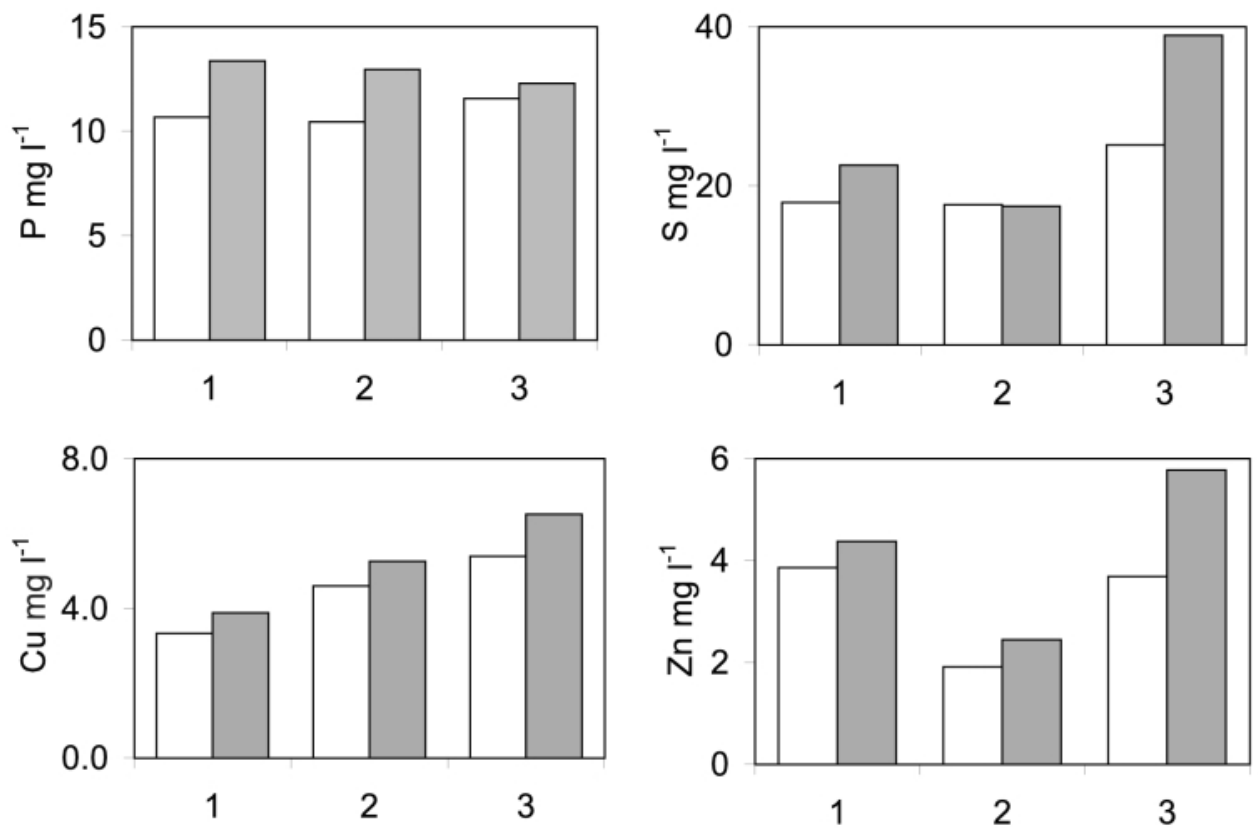

Fig. 3. Means of extractable phosphorus (P), sulphur (S), copper $(\mathrm{Cu})$ and zinc $(\mathrm{Zn})$ by the soil type groups, $1=$ coarse grained minerogenic soils, 2 = clay soils, $3=$ organic soils, in $1987(\square)$ and in $1998(\square)$.

Magnesium. Soil Mg was 4\% higher in 1998 than in 1987 owing to the higher amounts of $\mathrm{Mg}$ added to the soil with mineral fertilisers. During the previous monitoring period, the mean annual $\mathrm{Mg}$ input from fertilisers was $3.7 \mathrm{~kg} \mathrm{ha}^{-1}$ and during the present period $4.7 \mathrm{~kg} \mathrm{ha}^{-1}$. However, at the closing years of the 1990s, annual $\mathrm{Mg}$ inputs from fertilisers were less than $3 \mathrm{~kg}$ $\mathrm{ha}^{-1}$. Another source of $\mathrm{Mg}$ was liming agents, mean annual sales of which increased after 1987; statistics on the input rates were not, however, available. Magnesium concentrations were lowest in coarse grained minerogenic soils. According to the analytical data of Viljavuuspalvelu (2002) soil Mg in the Finnish fields increased from 1986-90 to 1996, but decreased thereafter.

Sulphur. In 1998, soil S was 18\% higher than in 1987. According to another monitoring study of Finnish cultivated soils, the $\mathrm{S}$ value rose by 15\% in 1992-1997 (Sippola et al. 2001). Both emissions and bulk depositions of S decreased markedly during this monitoring period. Other potential sources of $\mathrm{S}$ in the soil are fertilisers and animal manure. Mineral fertilisers sold by Kemira Agro (2002) for cereals, grass, beets and potatoes in Finland contain 2-3\%, 2-3\%, 8\% and $10-17 \%$ S, respectively. At the end of 1980 s, the contents were lower (Hero 2001, personal communication). There were no analytical data on the $\mathrm{S}$ content of animal manure in Finland. In Sweden, cattle and swine solid manure contained about $0.5 \% \mathrm{~S}$ in dry matter (Steineck et al. 1999, Eriksson 2001). The introduction of new feeding regimes and animal handling systems has caused major changes to the contents of some nutrients in animal manure since 1950s. In Denmark, the mean $\mathrm{S}$ input from animal manure into the cultivated soils at country level was estimated to be $8 \mathrm{~kg}$ in 1994 (Eriksen 1997). In 1998, organic soils contained more $\mathrm{S}$ than did the other soil type groups (Fig. 3), which explains the higher $\mathrm{S}$ concentrations in the soils of northern Finland (Fig. 4). 


\section{AGRICULTURAL AND FOOD SCIENCE IN FINLAND}

Vol. 11 (2002): 273-284.
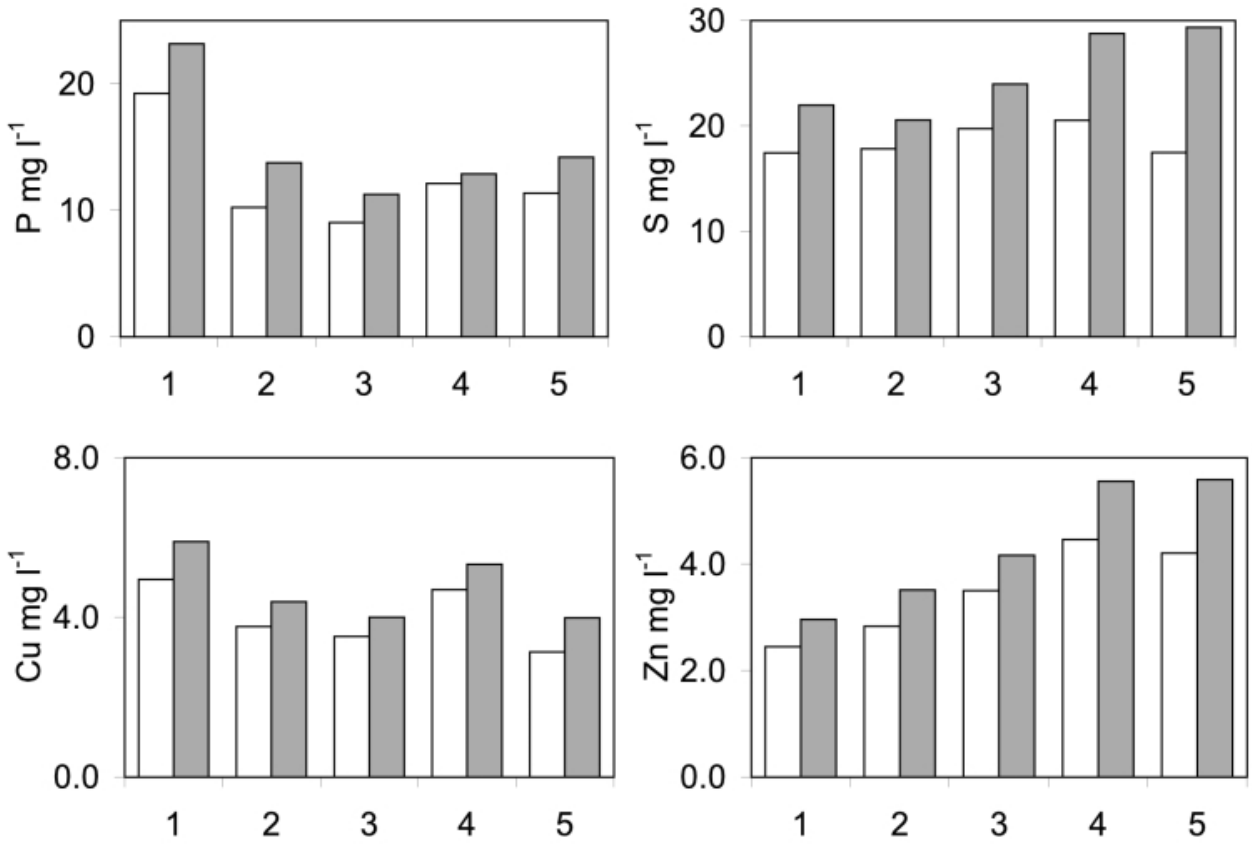

Fig. 4. Means of extractable phosphorus $(\mathrm{P})$, sulphur $(\mathrm{S})$, copper $(\mathrm{Cu})$ and zinc $(\mathrm{Zn})$ by the plant cultivation zones, 1-5, in $1987(\square)$ and in $1998(\square)$.

\section{Microelements and Al}

Aluminium. Extractable Al was unchanged in 1998 (Table 1), being at the same level as in 1987 (Erviö et al. 1990). Concentrations of soluble forms of $\mathrm{Al}$ are known to depend on the $\mathrm{pH}$ level of the soils, and hence the Al values were higher in organic soils than in the other soil type groups, on average.

Boron. From 1987 to 1998, soil B decreased. The change was due to the marked reduction in $\mathrm{B}$ fertilisation, the amount of $\mathrm{B}$ applied to the soil in mineral fertilisers being $242 \mathrm{~g} \mathrm{ha}^{-1}$ in 1987 and $95 \mathrm{~g} \mathrm{ha}^{-1}$ in 1998. The B values were highest in the southernmost Finland.

Cadmium. In 1998, soil Cd was at the same level as it had been in 1987 (Table 1). P fertilisers are usually the main source of $\mathrm{Cd}$ in the cultivated soil. The $\mathrm{Cd}$ concentration of $\mathrm{P}$ fertilisers depends on the $\mathrm{Cd}$ content of the phosphate used as raw material. In the early 1980s, a phosphate mine was opened at Siilinjärvi, and since then $\mathrm{Cd}$ inputs from fertilisers have decreased gradually. Since 1986, only 30-100 mg Cd has been allowed in each $\mathrm{kg}$ of fertiliser P. In 1999, a mean annual $\mathrm{Cd}$ input from the mineral fertilisers was $0.025 \mathrm{~g} \mathrm{ha}^{-1}$ (Mäkelä-Kurtto and Sippola 2001). Surveys of atmospheric heavy metal deposition monitored by moss analyses in the Nordic countries since 1969 and later in other European countries, too, indicate a steady decline in depositions of most heavy metals (Rühling and Steinnes 1998, Finnish Forest Research Institute 2001). In Finland, total annual emissions of $\mathrm{Cd}$ into the air from various sources fell by $80 \%$ from $6.3 \mathrm{t}$ in 1990 to $1.1 \mathrm{t}$ in 1997 (Melanen et al. 1999). In 1996, domestic sources contributed 33\%, natural and global sources 17\% and emissions from Russia, Poland and the United Kingdom combined $28 \%$ of total Cd depositions in Finland (Ryaboshapko et al. 1999). In 1997-1999, the mean Cd deposition was $0.19 \mathrm{~g}$ $\mathrm{ha}^{-1} \mathrm{yr}^{-1}$ with a range of 0.04 to $0.41 \mathrm{~g} \mathrm{ha}^{-1} \mathrm{yr}^{-1}$ (Leinonen 1999a, b, Waldén et al. 1999, Leino- 
Mäkelä-Kurtto, R. \& Sippola, J. Monitoring of Finnish arable land

nen 2000). Cadmium depositions, like soil Cd, decreased northwards. In the mid-1990s, average total $\mathrm{Cd}$ input to cultivated soil was lower in Finland than in any other OECD countries (Folke and Landner 1996). The results of static and dynamic mass balance estimates (Ministry of Agriculture and Forestry 1997, Louekari et al. 2000, Mäkelä-Kurtto and Sippola 2001) show that $\mathrm{Cd}$ inputs to the soil from various sources and $\mathrm{Cd}$ outputs from the soil to crops and waters are in balance. Hence, no significant change in soil $\mathrm{Cd}$ could be observed in the present study.

Cobalt. A slight decrease in soil Co was obvious in 1987-1998. No data on the Co inputs into cultivated soils or on the changes in them with time were available in Finland.

Chromium. Soil Cr level rose by $6 \%$ in $1987-$ 1998 , which was less than in the previous monitoring period (Erviö et al. 1990). This is most probably a consequence of the reduction in $\mathrm{Cr}$ emissions into the air, from $32 \mathrm{t}$ in 1990 to $21 \mathrm{t}$ in 1997 (Melanen et al. 1999). In 1997-1999, an estimated average $\mathrm{Cr}$ input via atmospheric deposition was $0.52 \mathrm{~g} \mathrm{ha}^{-1} \mathrm{yr}^{-1}$, ranging from $0.13 \mathrm{~g} \mathrm{ha}^{-1} \mathrm{yr}^{-1}$ in northern Finland to $1.32 \mathrm{~g}$ $\mathrm{ha}^{-1} \mathrm{yr}^{-1}$ in the south of the country (Leinonen 1999a, b, Waldén et al. 1999, Leinonen 2000). In Sweden, the $\mathrm{Cr}$ contents of animal manure were about $10 \mathrm{mg} \mathrm{kg}^{-1}$ dry matter (Eriksson 2001) and have declined since the 1970s (Steineck et al. 1999). In Finland, no analytical results were available on the $\mathrm{Cr}$ contents of animal manure. According to the estimates of Mäkelä-Kurtto and Sippola (2001), the average annual $\mathrm{Cr}$ input from mineral fertilisers in Finland was typically $2.8 \mathrm{~g} \mathrm{ha}^{-1}$ and from liming agents $7.7 \mathrm{~g} \mathrm{ha}^{-1}$ in 1999 . The highest median Cr content in 1998 was recorded in soils in northern Finland.

Copper. The median value of soil $\mathrm{Cu}$ in 1998 was $17 \%$ higher than that in 1987 (Table 1). The rate of increase was, however, slower than it had been in 1974-1987 (Erviö et al. 1990). The difference between the two monitoring periods was mainly due to the reduction in $\mathrm{Cu}$ inputs from mineral fertilisers by nearly $90 \%$, from $275 \mathrm{~g}$ $\mathrm{ha}^{-1}$ in 1987 to $33 \mathrm{~g} \mathrm{ha}^{-1}$ in 1998. Moreover, annual $\mathrm{Cu}$ emissions from domestic sources decreased by $23 \%$ from 94 to $72 \mathrm{t}$, in the $1990 \mathrm{~s}$ (Melanen et al. 1999). In 1997-1999, the mean bulk deposition of $\mathrm{Cu}$ was $5.1 \mathrm{~g} \mathrm{ha}^{-1} \mathrm{yr}^{-1}$, ranging from 3.0 to $9.4 \mathrm{~g} \mathrm{ha}^{-1} \mathrm{yr}^{-1}$ and being highest in the south of the country (Leinonen 1999a, b, Waldén et al. 1999, Leinonen 2000). In 1997, an average $\mathrm{Cu}$ input from the total amount of animal manure generated was estimated to be $105 \mathrm{~g} \mathrm{ha}^{-1}$, if the manure is considered to be applied evenly to the whole cultivated area (Mäkelä-Kurtto and Sippola 2001). According to Mäkelä-Kurtto and Sippola (2001) the soil $\mathrm{Cu}$ balance was clearly positive at the end of 1990s, which was a reason for the increase in soil $\mathrm{Cu}$ value observed here. The highest $\mathrm{Cu}$ value was in organic soils and the lowest one in coarse grained minerogenic soils, on average (Fig. 3), but differences were small. There was not a clear geographical trend in the $\mathrm{Cu}$ values (Fig. 4).

Iron. After 1987, soil extractable Fe increased by $4 \%$. Organic soils had higher concentrations of Fe than did the other soil type groups. In 1997-1999, approximately 10 times as much Fe was deposited annually in the southern Finland, 200-300 $\mathrm{g} \mathrm{ha}^{-1}$, as in the north, 25-40 $\mathrm{g} \mathrm{ha}^{-1}$ (Leinonen 1999a, b, 2000). The highest median of soil Fe was in cultivation zone IV.

Manganese. Soil Mn remained unchanged in 1987-1998, there being no major changes in average annual $\mathrm{Mn}$ inputs from mineral fertilisers between the monitoring periods: $199 \mathrm{~g} \mathrm{ha}^{-1}$ in 1974-1986 and $216 \mathrm{~g} \mathrm{ha}^{-1}$ in 1987-1998, on average (Kemira Agro 1999). The highest Mn values were recorded in organic soils and in the northernmost cultivation zone.

Molybdenum. In 1987-1998, soil Mo started to decline, particularly in organic soils. The lowest median of soil Mo was in the cultivation zone IV.

Nickel. No change in soil Ni occurred in the period 1987-1998, although national Ni emissions into the air fell by $60 \%$, from $67 \mathrm{t}$ in 1990 to $28 \mathrm{t}$ in 1997 (Melanen et al. 1999). The average Ni input via atmospheric deposition in 1997- 
Vol. 11 (2002): 273-284.

1999 was $1.5 \mathrm{~g} \mathrm{ha}^{-1} \mathrm{yr}^{-1}$, ranging from $0.8 \mathrm{~g}$ $\mathrm{ha}^{-1} \mathrm{yr}^{-1}$ in the north to $2.5 \mathrm{~g} \mathrm{ha}^{-1} \mathrm{yr}^{-1}$ in the south of Finland (Leinonen 1999a, b, 2000). According to Swedish studies (Eriksson 2001) Ni contents in animal manure were about $5 \mathrm{mg} \mathrm{kg}^{1}$ dry matter and have decreased slightly since the 1970s (Steineck et al. 1999). Even though we lack evidence as yet, $\mathrm{Ni}$ inputs from manure to cultivated soils may be of importance in Finland, too. In 1999, the average amount of $\mathrm{Ni}$ added via mineral fertilisers was $1.5 \mathrm{~g} \mathrm{ha}^{-1}$ and via liming agents $6.1 \mathrm{~g} \mathrm{ha}^{-1}$ (Mäkelä-Kurtto and Sippola 2001). In 1998, Ni concentrations in soils were higher in the south than in the north of Finland and higher in the clay soils than in the other soil type groups.

Selenium. Selenium was included in the monitoring program for the first time. Concentrations of Se decreased northwards. In 1984, it became legal to add Se to all mineral fertilisers sold in Finland owing to the low soil Se content and insufficient $S e$ concentrations in food, cereals in particular, and in feedstuffs. Fertilisers have contained 6-16 $\mathrm{mg} \mathrm{kg}^{-1} \mathrm{Se}$.

Zinc. In 1987, many of Finland's fields were low in $\mathrm{Zn}$. The need to raise the $\mathrm{Zn}$ concentration in feedstuffs led to an increase in $\mathrm{Zn}$ fertilisation. In 1987-1998, the median of soil $\mathrm{Zn}$ increased by $16 \%$ (Table 1), largely due to the increase in annual $\mathrm{Zn}$ inputs from mineral fertilisers, from $60 \mathrm{~g} \mathrm{ha}^{-1}$ in $1974-1986$ to $136 \mathrm{~g} \mathrm{ha}^{-1}$ in 1987-1998. Thus, $\mathrm{Zn}$ additions from fertilisers more than doubled during this monitoring period. However, $\mathrm{Zn}$ emissions into the atmosphere fell by $85 \%$ from, $571 \mathrm{t}$ to $70 \mathrm{t}$ per year, in the $1990 \mathrm{~s}$ (Melanen et al. 1999). In 1997-1999, the mean $\mathrm{Zn}$ input from the atmosphere was $20.2 \mathrm{~g} \mathrm{ha}^{-1}$ $\mathrm{yr}^{-1}$ and the range from 4.0 to $52.7 \mathrm{~g} \mathrm{ha}^{-1} \mathrm{yr}^{-1}$ (Leinonen 1999a, b, 2000). Average Zn deposition was about three times as high in southernmost as in northernmost Finland. The lowest mean $\mathrm{Zn}$ value was in clay soils (Fig. 3). Soil $\mathrm{Zn}$ increased northwards (Fig. 4), as organic soils and grasslands, which needs $\mathrm{Zn}$-rich fertilisation, are located mainly in the north of country. The positive mass balance of soil $\mathrm{Zn}$ recorded by Mäkelä-Kurtto and Sippola (2001) in the late 1990s is consistent with the increase in soil $\mathrm{Zn}$ found here.

\section{Conclusions}

Between 1987 and 1998, the most significant changes in the soil nutrient concentrations seemed to occur in those of $\mathrm{P}, \mathrm{S}, \mathrm{Cu}$ and $\mathrm{Zn}$, which rose by nearly $20 \%$. Small increases occurred in soil $\mathrm{Ca}, \mathrm{Mg}$ and $\mathrm{Fe}$. The decreases found in soil K, B, Co and Mo values were minor. Most of the changes in the soil nutrients could be attributed to changes in the use of nutrients in mineral fertilisers. The exceptions were the soil $\mathrm{P}$ and $\mathrm{Cu}$, which increased even though use of these nutrients declined markedly during the study period. However, total inputs of $\mathrm{P}$ and $\mathrm{Cu}$ into the soil were still so high that the mass balances continued to be strongly positive, leading to the nutrient increases documented here. The major increase in soil $\mathrm{Zn}$ was mainly due to the heavy increase in fertiliser $\mathrm{Zn}$, a finding that was also supported by the positive mass balance in soils. The trend in soil P observed here may aggravate the risk of eutrophication, whereas trends in soil $\mathrm{Ca}, \mathrm{Mg}, \mathrm{Cu}$ and $\mathrm{Zn}$ may lead to improvements in the quality of crops.

As to harmful heavy metals, soil $\mathrm{Cd}$ and $\mathrm{Ni}$ concentrations did not change, but that of $\mathrm{Cr}$ increased slightly. Clear reductions in the $\mathrm{Cd}$ inputs from fertilisers and the atmosphere compared with the previous monitoring period brought soil $\mathrm{Cd}$ inputs and outputs into balance. This levelling-off of concentrations of $\mathrm{Cd}$ and $\mathrm{Ni}$ in the soil is a positive sign for the agro-ecosystem and agricultural products, too.

The level of soil acidity rose, even though use of liming agents increased and acidifying depositions declined noticeably. The main reason would seem to be the increase in the use of fertiliser N. Acidification of the cultivated soils is undesirable because it may reduce the availability of nutrients and increase the availability of heavy metals to plants and also accelerate leaching of the metals to waters. 


\section{Mäkelä-Kurtto, R. \& Sippola, J. Monitoring of Finnish arable land}

Acknowledgements. The authors warmly thank the staff of the Environmental Research and Ecological Farming units of MTT Agrifood Research Finland for participating in the large-scale sampling operation in 1998, and also the labo- ratory staff for their skilled analyses of the samples. The authors are very grateful to Mrs. Gillian Häkli for kindly revision of the English of this article.

\section{References}

Agricultural Research Centre 1986. Methods of Soil and Plant Analysis. Agricultural Research Centre, Department of Soil Science. SF-31600 Jokioinen. Finland. $45 \mathrm{p}$.

Botkin, D. \& Keller, E. 1995. World food supply. In: Environmental Science - Earth as a Living Planet. New York: John Wiley \& Sons, Inc. p. 176-196.

Eriksen, J. 1997. Animal manure as $S$ fertilizer. Sulphur in Agriculture 20: 27-30.

Eriksson, J. 2001. Concentrations of 61 trace elements in sewage sludge, farmyard manure, mineral fertiliser, precipitation and in oil and crops. Swedish Environmental Protection Agency Report 5159. 45 p.

Erviö, R. 1995. Viljelymaan humuspitoisuuden muuttuminen ja siihen vaikuttaminen Summary: Change in and ways of affecting the humus content of arable land. Maatalouden tutkimuskeskus Tiedote 11/95. Jokioinen. p. 1-12.

Erviö, R. 1970. The importance of soil bulk density in soil testing. Annales Agriculturae Fenniae 9: 278-286.

Erviö, R., Mäkelä-Kurtto, R. \& Sippola, J. 1990. Chemical characteristics of Finnish agricultural soils in 1974 and in 1987. In: Kauppi, P. et al. (eds.). Acidification in Finland. Berlin: Springer-Verlag. p. 217-234.

Finnish Forest Research Institute 2001. Raskasmetallikartoitus -raskasmetallilaskeuma Suomessa 19852000 (Heavy metal survey - heavy metal deposition in Finland 1985-2000. Cited 9 April 2002. Updated 11 December 2001. Available on the Internet: http:// www.metla.fi/metinfo/metsienterveys/raskasmetalli/

Folke, J. \& Landner, L. 1996. Sustainable cadmium management in agriculture: Balancing the cadmium fluxes in arable land and grassland. In: OECD Proceedings - Fertilizers as a Source of Cadmium. Paris: IOMC. p. 113-118.

Gibson, C.E. 1997. The dymanics of phosphorus in freshwater and marine environments. In: Tunney, H. et al. (eds.). Phosphorus Loss from Soil to Water. London: CAB international. p. 119-135.

Jalkanen, L. 2000. Trace elements in the atmosphere in Finland. In: Jalkanen, L. (eds.). Atmospheric inorganic trace contaminants in Finland, especially in the Gulf of Finland area. Finnish Meteorological Institute Contributions 29: 26 p.

Jansson, H. 1995. Status of sulphur in soils and plants of thirty countries. World Soil Resources Reports 79. $101 \mathrm{p}$.
Kemira Agro 1999. Lannoitteiden myynnin jakautuminen maaseutukeskusalueittain lannoitusvuonna 1998/99 (Statistics on fertilizer sales). Kemira Agro Ltd. 11 p. Kemira Agro 2002. Kasvuohjelma: Kasvuohjelman puhtaat lannoitteet (Plant growth programme: clean domestic fertilisers of the plant growth programme). Leipä leveämmäksi 50, 1: 63.

Lakanen, E. \& Erviö, R. 1971. A comparison of eight extractants for the determination of plant available micronutrients in soils. Acta Agriculturae Fenniae 128: 223-232.

Leinonen, L. 1999a. Air quality Measurements 1997. Helsinki: Finnish Meteorological Institute, Air Quality Measurements. $174 \mathrm{p}$.

Leinonen, L. 1999b. Air quality Measurements 1998. Helsinki: Finnish Meteorological Institute, Air Quality Measurements. $175 \mathrm{p}$.

Leinonen, L. 2000. Air quality Measurements 1999. Helsinki: Finnish Meteorological Institute, Air Quality Measurements. $254 \mathrm{p}$.

Louekari, K., Mäkelä-Kurtto, R., Pasanen, J., Virtanen, V., Sippola, J. \& Malm, J. 2000. Cadmium in Fertilizers - Risks to human health and the environment. Ministry of Agriculture and Forestry in Finland, Publications 4/2000. 119 p.

Mäkelä-Kurtto, R. \& Sippola, J. 2001. Finland. In: Assessment and reduction of heavy metal input into agroecosystems AROMIS. Report of the first meeting, Cemagref, France. Darmstadt: Kuratorium fûr Technik und Bauwesen in der Landwirtschaft e.V. p. 6176.

Melanen, M., Ekqvist, M., Mukherjee, A.B., Aunela-Tapola, L., Verta, M. \& Salmikangas, T. 1999. Raskasmetallien päästöt ilmaan Suomessa 1990-luvulla (Summary: Atmospheric emissions of heavy metals in Finland in the 1990s). Suomen ympäristö 329. Helsinki: Finnish Environment Institute. 86 p.

Ministry of Agriculture and Forestry 1997. Cadmium in Fertilizers - Risks to Human Health and the Environment. Publications of the Ministry of Agriculture and Forestry 9/1997. $93 \mathrm{p}$.

Oliver, M.A. 1997. Soil and human health: a review. European Journal of Soil Science 48: 573-592.

Palva, R., Rankinen, K., Granlund, K., Grönroos, J., Nikander, A. \& Rekolainen, S. 2001. Maatalouden ympäristötuen toimenpiteiden toteutuminen ja vaikutukset vesistökuormitukseen vuosina 1995-1999 
Vol. 11 (2002): 273-284.

(Abstract: Environmental Impacts of Agri-Environmental Support Scheme in 1995-1999). Suomen Ympäristö (Finnish Environment) 478. Helsinki: Oy Edita Ab. 92 p.

Rekolainen, S., Ekholm, B., Ulén, B. \& Gustafson, A. 1997. Phosphorus losses from agriculture to surface waters in the Nordic countries. In: Tunney, H. et al. (eds.). Phosphorus Loss from Soil to Water. London: CAB international. p. 77-93.

Ryaboshapko, A., Ilyin, I., Gusev, A., Afinogeva, O., Berg, T. \& Hjellbrekke, A.-G. 1999. Monitoring and modelling of lead, cadmium and mercury transboundary transport in the atmosphere of Europe. Joint report of EMEP Centres: MSC-E and CCC. EMEP report 3/ 99, Meteorological Synthesizing Centre - East, Moscow, Russia. ref.: Jalkanen, L. 2000.

Rühling, Å. \& Steinnes, E. 1998. Atmospheric heavy metal deposition in Europe 1995-1996. Nord 1998: 15. 66 p.

Saarinen, K. 2001. Happamoittavat päästöt (Acidifying emissions in Finland). Ympäristö 15, 3: 20-21.

SAS 1999. SAS/STAT Users Guide, Version 8, SAS Institute Inc. Cary, NC.

Sillanpää, M. 1982. Micronutrients and the nutrient status of soils: a global study. FAO Soils Bulletin 48.444 p.

Sillanpää, M. 1990. Micronutrient assessment at the country level: an international study. FAO Soils Bulletin 63. $208 \mathrm{p}$.

Sillanpää, M. \& Jansson, H. 1992. Status of cadmium, lead, cobalt and selenium in soils and plants of thirty countries. FAO Soils Bulletin 65. $195 \mathrm{p}$.

Sippola, J., Kivistö, P. \& Mäkelä-Kurtto, R. 2001. Tutkimusasemien viljelymaiden ravinne- ja raskasme- tallipitoisuuksien seuranta. Muutokset aikavälillä 1992-1997. MTT:n julkaisuja. Sarja B 27. Jokioinen: MTT. $13 \mathrm{p}$.

Sippola, J. \& Tares, T. 1978. Soluble content of mineral elements in cultivated soils. Acta Agriculturae Scandinavica, Supplementum 20: 11-25.

Starr, M., Lehtinen, H., Sippola, J. \& Tarvainen, T. 2000. Soil monitoring programmes in Finland. Pro Terra 4/ 2000: 13-15.

Steineck, S., Gustafson, G., Andersson, A., Tersmeden, M. \& Bergström, J. 1999. Stallgödselns innehåll av växtnäring och spårelement (Animal manure - contents of nutrients and trace elements). Naturvårdsverket Rapport 4974. 28 p.

Viljavuuspalvelu 2000. Viljavuustutkimuksen tulkinta peltoviljelyssä (Interpretation of analytical results of soil testing for field cultivation). Viljavuuspalvelu Ltd. $31 \mathrm{p}$.

Viljavuuspalvelu 2002. Tilastot (Statistics). Cited 11 March 2002. Updated: no date. Available on the Internet: http://www.viljavuuspalvelu.fi/stat.htm

Vuorinen, J. \& Mäkitie, O. 1955. The method of soil testing in use in Finland. Agrogeological Publications 63: $1-44$.

Waldén, J., Ruoho-Airola, T. \& Leinonen, L. 1999. Background air quality in Finland in 1997. Finnish Forest Research Institute, Research Papers 743: 14-30.

Yli-Halla, M., Nykänen, A., Siimes, K. \& Tuhkanen, H.-R. 2001. Ympäristötuen ehdot ja maan helppoliukoisen fosforin pitoisuus (Agri-Environmental Programme regulations and the easily soluble phosphorus concentration in soil). MTT:n julkaisuja, Sarja A77. Jokioinen: MTT. $45 \mathrm{p}$. 


\title{
SELOSTUS
}

\section{Suomalaisten viljelymaiden tilan seuranta: muutoksia peltojen ominaisuuksissa aikavälillä 1987-1998}

\author{
Ritva Mäkelä-Kurtto ja Jouko Sippola \\ MTT (Maa- ja elintarviketalouden tutkimuskeskus)
}

Tutkimus oli osa viljelymaiden pitkäaikaista seurantaa, joka on alkanut vuonna 1974 ja jonka tavoitteena on ollut tuottaa aikaan ja paikkaan sidottua tietoa peltojen kemiallisista ominaisuuksista ja niissä tapahtuneista muutoksista. Tämän tutkimusosuuden tarkoituksena oli seurata maan ominaisuuksien kehittymistä aikavälillä 1987-1998. Tavoitteena oli saada kattava kuva peltomaiden tilasta vuonna 1998 sekä peltomaissa tapahtuneista muutoksista vuodesta 1987 ja muutosten aiheuttajista. Maanäytteet kerättiin vuonna 1998 samoilta 705 peltolohkolta, jotka sijoittuivat tasaisesti koko viljellylle alueelle, ja analyysituloksia verrattiin vuoden 1987 vastaaviin tuloksiin. Näytteistä määritettiin maalaji, $\mathrm{pH}$, orgaaninen hiili (C), johtoluku, tilavuuspaino, helppoliukoiset pää- ja hivenravinteet sekä helppoliukoiset raskasmetallit. Analyysimenetelmät olivat samat kuin tavanomaisessa viljavuustutkimuksessa. Fosfori, kalium, kalsium, rikki ja magnesium uutettiin maanäytteistä liuokseen (AAAc, pH 4,65), joka oli 0,5 $\mathrm{M}$ ammoniumasetaatin ja 0,5 $\mathrm{M}$ etikkahapon suhteen, ja alumiini, kadmium, koboltti, kromi, kupari, rauta, mangaani, molybdeeni ja sinkki muuten edellisen kaltaiseen liuokseen (AAAc-EDTA, pH 4,65) paitsi, että liuos oli myös 0,02 M natriumetyleenidiamiinitetraetikkahapon $\left(\mathrm{Na}_{2}\right.$ EDTA) suhteen. Boorin ja seleenin määrittämiseksi maanäytteet uutettiin kuumaan veteen. Johtoluku ja pH mitattiin vesiuutteesta.
Merkittävimpiä ravinnemuutoksia vuodesta 1987 vuoteen 1998 olivat helppoliukoisen fosforin, rikin, kuparin ja sinkin lisääntyminen lähes 20 prosentilla. Kalsiumin, magnesiumin ja raudan pitoisuudet lisääntyivät hiukan, ja kaliumin, boorin, koboltin ja molybdeenin pitoisuudet vähenivät lievästi. Muutokset peltojen ravinnepitoisuuksissa olivat yleensä seurausta lannoitteiden käyttömäärissä tapahtuneista vastaavista muutoksista. Sen sijaan fosfori- ja kuparipitoisuudet nousivat, vaikka vastaavat ravinnelisäykset lannoitteissa huomattavasti vähenivät tutkimusjakson aikana. Fosfori- ja kuparipitoisuuksien nousun maassa selitti se, että näiden aineiden lisäykset maahan olivat kuitenkin vielä selvästi suuremmat kuin näiden aineiden poistumat maasta.

Viljelymaiden todettiin lievästi happamoituneen, vaikka kalkitusaineiden käyttö lisääntyi. Lasku pHluvussa johtui ilmeisesti siitä, että lannoitetyppeä käytettiin aikavälillä 1987-1998 keskimäärin jonkin verran runsaammin kuin edellisellä tutkimusjaksolla 1974-1987.

Haitallisten raskasmetallien pitoisuudet kehittyivät suotuisasti, sillä helppoliukoisen kadmiumin ja nikkelin pitoisuudet maassa pysyivät ennallaan ja kromin pitoisuus kasvoi vain vähän. Syy myönteiseen kehitykseen oli raskasmetallipäästöjen ja -laskeumien oleellinen pieneneminen. 